\title{
Communication \\ Single Cell Analysis of Bistable Expression of Pathogenicity Island 1 and the Flagellar Regulon in Salmonella enterica
}

\author{
María Antonia Sánchez-Romero ${ }^{1, *(D)}$ and Josep Casadesús ${ }^{2}$ \\ 1 Departamento de Microbiología y Parasitología, Facultad de Farmacia, Universidad de Sevilla, \\ Calle Profesor García González, 2, 41012 Seville, Spain \\ 2 Departamento de Genética, Facultad de Biología, Universidad de Sevilla, Apartado 1095, 41080 Seville, Spain; \\ casadesus@us.es \\ * Correspondence: mtsanchez@us.es
}

Citation: Sánchez-Romero, M.A.; Casadesús, J. Single Cell Analysis of Bistable Expression of Pathogenicity Island 1 and the Flagellar Regulon in Salmonella enterica. Microorganisms 2021, 9, 210. https://doi.org/ 10.3390/microorganisms 9020210

Academic Editor: Tassos Economou Received: 28 December 2020

Accepted: 18 January 2021

Published: 20 January 2021

Publisher's Note: MDPI stays neutral with regard to jurisdictional claims in published maps and institutional affiliations.

Copyright: (c) 2021 by the authors. Licensee MDPI, Basel, Switzerland. This article is an open access article distributed under the terms and conditions of the Creative Commons Attribution (CC BY) license (https:// creativecommons.org/licenses/by/ $4.0 /)$.

\begin{abstract}
Bistable expression of the Salmonella enterica pathogenicity island 1 (SPI-1) and the flagellar network (Flag) has been described previously. In this study, simultaneous monitoring of OFF and ON states in SPI-1 and in the flagellar regulon reveals independent switching, with concomitant formation of four subpopulations: SPI- ${ }^{\text {OFF }}$ Flag ${ }^{\text {OFF }}$, SPI- $1^{\text {OFF }}$ Flag $^{\text {ON }}$, SPI-1 ${ }^{\text {ON }}$ Flag $^{\text {OFF }}$, and SPI-1 ${ }^{\text {ON }}$ Flag $^{\text {ON }}$. Invasion assays upon cell sorting show that none of the four subpopulations is highly invasive, thus raising the possibility that Flag ${ }^{\text {OFF }}$ cells might contribute to optimal invasion as previously proposed for SPI-1 ${ }^{\text {OFF }}$ cells. Time lapse microscopy observation indicates that expression of the flagellar regulon contributes to the growth impairment previously described in SPI-1 ${ }^{\mathrm{ON}}$ cells. As a consequence, growth resumption in SPI- ${ }^{\mathrm{ON}}$ Flag ${ }^{\mathrm{ON}}$ cells requires switching to both SPI-1 $\mathrm{OFF}$ and Flag ${ }^{\text {OFF }}$ states.
\end{abstract}

Keywords: phenotypic heterogeneity; bistability; epithelial cell invasion; SPI-1; flagellar regulon

\section{Introduction}

Invasion of epithelial cells by Salmonella enterica requires the activity of effectors secreted through the type III secretion system (T3SS) of pathogenicity island 1 (SPI-1). In the mammalian ileum and under reductionist laboratory conditions that mimic the intestine, expression of SPI-1 genes is bistable, yielding SPI- ${ }^{\mathrm{OFF}}$ and SPI- $1^{\mathrm{ON}}$ subpopulations [1-3]. The mechanism that controls SPI-1 bistability remains unknown but probably depends on complex interactive networks and feedback loops involving SPI-1 regulators [4]. Some such regulators control crosstalk between SPI-1 and other gene networks, and an example is the flagellar regulon [4-6].

A peculiar trait of SPI- $1^{\mathrm{ON}}$ cells is reduced growth rate [7], caused by the energetic burden of building the secretion apparatus, by disruption of the proton gradient during T3SS assembly, or by the energy expense invested in both processes. However, growth retardation associated to SPI-1 expression confers increased antibiotic resistance to SPI-1 ${ }^{\mathrm{ON}}$ cells [8].

Bacterial motility contributes to invasion by fostering bacterial contact with host cells [9] and by helping to choose optimal infection sites [10,11]. Flagella-mediated adhesion may also contribute to triggering membrane ruffling and concomitant initiation of epithelial cell invasion [12]. Furthermore, flagellin has been shown to be a potent activator of the innate immune response $[13,14]$. Like SPI-1, the S. enterica flagellar regulon shows bimodal expression [15], and formation of flagellated and non-flagellated subpopulations is under the control of multiple regulators [11,15-18].

While the contribution of SPI-1 and the flagellar network to epithelial cell invasion has been studied with exquisite detail, certain questions have remained unanswered because they demanded single cell analysis. One such question is whether SPI-1 and the flagellar regulon undergo independent or co-ordinated switching; another is whether flagellar 
expression, alone or together with SPI-1 expression, alters S. enterica growth. In this study, simultaneous monitoring of OFF and ON states in SPI-1 and the flagellar regulon has permitted visualization of four subpopulations (SPI-1 ${ }^{\text {OFF }}$ Flag ${ }^{\mathrm{OFF}}$, SPI- ${ }^{\mathrm{OFF}} \mathrm{Flag}^{\mathrm{ON}}$, SPI$1^{\mathrm{ON}}$ Flag ${ }^{\mathrm{OFF}}$, and SPI-1 ${ }^{\mathrm{ON}}$ Flag ${ }^{\mathrm{ON}}$ ), indicating that independent switching occurs. In vitro assays using sorted (sub)populations have provided evidence that cells that express SPI-1 and flagella are not optimally invasive, suggesting that both Flag ${ }^{\mathrm{OFF}}$ and Flag ${ }^{\mathrm{ON}}$ cells may contribute to optimal epithelial cell invasion. We also show that expression of the flagellar regulon contributes to the growth impairment of SPI- ${ }^{\mathrm{ON}}$ cells.

\section{Materials and Methods}

\subsection{Bacterial Strains, Media and Culture Conditions}

Strains of Salmonella enterica serovar Typhimurium used in this study derive from the mouse-virulent strain SL1344. For simplicity, Salmonella enterica serovar Typhimurium

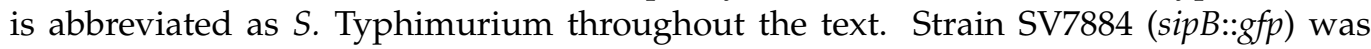
described elsewhere [3]. A transcriptional fusion with the $m$ Cherry gene was constructed downstream of the stop codon of fliC. For this purpose, a DNA fragment containing the promoterless $m$ Cherry gene and the kanamycin resistance cassette was PCR-amplified from pDOC-R, an $m$ Cherry-containing derivative of plasmid pDOC (a gift from Busby's lab, Univ. Birmingham, UK), using primers 5'GAA CCA GGT TCC GCA AAA CGT CCT CTC TTT ACT GCG TTA AGG GTA CCA TGG TGA GCA AGG 3' and 5'CTG CCT TGA TTG TGT ACC ACG TGT CGG TGA ATC AAT CGC CAA CCT CGA GAT ATG AAT ATC 3'. The PCR product was integrated into the chromosome of SL1344 using the Lambda Red recombination system [19], generating strain SV7819 (fliC::mCherry). P22 HT-mediated transduction was used to generate strain SV8533 (sipB:::fp fliC::mCherry) using SV7819 (fliC:: $m$ Cherry) as donor and SV7884 (sipB::gfp) as recipient. Cultures were grown at $37^{\circ} \mathrm{C}$ in borosilicate tubes containing $5 \mathrm{~mL}$ of Bertani's lysogeny broth (LB). Oxygen limitation ("invasive" condition) was achieved by growth without shaking.

\subsection{Invasion Assays in HeLa Epithelial Cells}

HeLa human epithelial cells (ATCC CCL-2) were grown in DMEM containing 10\% fetal calf serum and $1 \mathrm{mM}$ glutamine (Life Technologies, Carlsbad, CA, USA). HeLa cells were seeded in 24-well plates (Costar, Corning) the day before the infection. Bacterial cultures were grown overnight at $37^{\circ} \mathrm{C}$ in LB without shaking in borosilicate tubes and added to HeLa cells to reach a multiplicity of infection (MOI) of 75 bacteria per eukaryotic cell. Thirty minutes after infection, cells were washed twice with phosphate buffered saline (PBS) and incubated in fresh DMEM medium containing $100 \mu \mathrm{g} / \mathrm{mL}$ gentamicin for $90 \mathrm{~min}$. Numbers of viable intracellular bacteria were obtained after lysis of infected cells with $1 \%$ Triton X-100, and plating on appropriate media. Infections were carried out in triplicate. Invasion rates were calculated as the ratio between viable intracellular bacteria and viable bacteria added to infect the HeLa cells.

\subsection{Flow Cytometry Analysis}

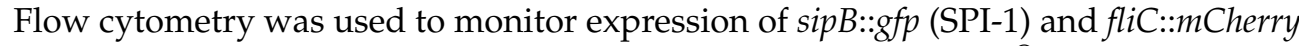
(flagella) fusions. Data acquisition was performed using a MACSQuant ${ }^{\circledR}$ Analyzer 10 flow cytometer (Miltenyi Biotec, Bergisch Gladbach, Germany) and was analyzed with FlowJo X v. 10.0.7r software (Tree Star, Inc., Ashland, OR, USA). S. Typhimurium strains were grown at $37^{\circ} \mathrm{C}$ until the desired optical density, washed, and re-suspended in PBS for fluorescence measurement by flow cytometry. Fluorescence values for 100,000 events were compared with the data from the reporter-less control strain, thus yielding the fraction of $\mathrm{ON}$ and OFF cells in SPI-1 and in the flagellar system.

\subsection{Fluorescence Activated Cell Sorting (FACS) of Live Cells}

Cells from an overnight culture were grown under invasive conditions. The culture was washed and re-suspended in PBS to a final concentration of $5 \times 10^{6}$ cells $/ \mathrm{mL}$. Cells 
were sorted using a MoFlo Astrios EQ cytometer (Beckman Coulter, Brea, CA). Immediately prior to sorting, cells were analyzed for GFP and/or mCherry expression. Based on this analysis, gates were drawn to separate cells that expressed both GFP (SPI-1) and mCherry (flagella) (SPI-1 ${ }^{\mathrm{ON}}$ Flag ${ }^{\mathrm{ON}}$ subpopulation) from cells that did not (SPI-1 ${ }^{\mathrm{OFF}}$ Flag ${ }^{\mathrm{OFF}}$ subpopulation), as well as cells that expressed either GFP (SPI-1) or mCherry (flagella) (SPI-1 ${ }^{\mathrm{ON}}$ Flag ${ }^{\mathrm{OFF}}$ and SPI-1 ${ }^{\mathrm{OFF}}$ Flag ${ }^{\mathrm{ON}}$ subpopulations). From each gate, cells were collected into a sterile tube. After sorting, cells were spun at $4000 \mathrm{rpm}$ for $10 \mathrm{~min}$. FACS buffer was then removed, and cells were re-suspended in DMEM to perform invasion assays. An aliquot of sorted cells was run again at the cytometer to confirm the purity of the preparation. Data were analyzed with FlowJo X v. 10.0.7r software (Tree Star, Inc.).

\subsection{Fluorescence Microscopy}

Strain SV8533 (sipB:::gfp fliC::mCherry) was grown in LB without shaking for $18 \mathrm{~h}$ at $37^{\circ} \mathrm{C}$. Samples of $1.5 \mathrm{~mL}$ were collected by centrifugation at $3400 \times \mathrm{g}$ for $5 \mathrm{~min}$. Cells were placed on an agarose slab $\left(0.9 \%\right.$ agarose $/ 1 \%$ LB medium) pre-warmed at $37^{\circ} \mathrm{C}$. Images were captured with a Zeiss Apotome fluorescence microscope equipped with a $100 \times$ Plan Apochromat objective lens and an incubation system that permits cultivation and observation of living cells $\left(37^{\circ} \mathrm{C}\right)$. Pictures were taken at different times using an Axiocam 506 camera, and the images were analyzed using ImageJ software (Wayne Rasband, Research Services Branch, National Institute of Mental Health, MD, USA).

\subsection{Statistical Analysis}

Student's t-test (two-tailed) was performed using GraphPad Prism v. 6.0 for Mac to determine statistical differences between two groups.

\section{Results}

\subsection{Single Cell Analysis of the Expression Pattern of Invasion and Motility Genes}

Simultaneous monitoring of OFF and ON states in SPI-1 and the flagellar regulon was performed using transcriptional fusions with GFP and mCherry fluorescent proteins. The fusions had been constructed downstream of the SPI-1 gene $\operatorname{sip} B$, which encodes a T3SS effector, and downstream of the flagellar gene $f l i C$, which encodes flagellin. The resulting strain (SV8533, sipB::gfp fliC::mCherry) was used to monitor the pattern of SPI-1 and flagellar expression using fluorescence microscopy and flow cytometry in cultures grown in invasive conditions (LB under oxygen limitation). Bistable expression of both SPI-1 and the flagellar system was observed (Figure 1 and Supplementary Figure S1). The subpopulation of SPI-1 ${ }^{\mathrm{ON}}$ cells was small as previously described [3] while the Flag ${ }^{\mathrm{ON}}$ subpopulation was large. Invasion and motility genes thus appear showing independent patterns of bimodal expression, and the subpopulation of cells that secrete SPI-1 invasion effectors and harbor flagella is small. Bistability was also observed under non invasive conditions (LB under aerobiosis) but the subpopulation sizes were different (Supplementary Figure S2).

\subsection{Contribution of Virulence and Motility Systems to Invasion of Epithelial Cells In Vitro}

Given the involvement of flagella in early steps of the invasion process, one might expect that Flag ${ }^{\mathrm{N}}$ cells would be more invasive than Flag ${ }^{\mathrm{OFF}}$ cells [15]. To test this hypothesis, epithelial cell invasion assays were performed using Flag OFF and FlagON subpopulations separated by cell sorting. Surprisingly, the Flag ${ }^{\mathrm{OFF}}$ subpopulation was as invasive as the Flag ${ }^{\mathrm{ON}}$ subpopulation (Figure 2B). Therefore, at first sight, cells that harbor flagella do not seem to be more invasive than cells that lack flagella. However, both Flag OFF and Flag ${ }^{\mathrm{ON}}$ subpopulations contain SPI-1-expressing and SPI-1-nonexpressing cells, and both are necessary for optimal invasion [3]. When sorted SPI-1 ${ }^{\text {OFF }}$ Flag ${ }^{\text {OFF }}$, SPI-1 ${ }^{\mathrm{ON}}$ Flag ${ }^{\text {OFF, }}$ SPI-1 ${ }^{\mathrm{OFF}}$ Flag ${ }^{\mathrm{ON}}$ and SPI-1 ${ }^{\mathrm{ON}}$ Flag ${ }^{\mathrm{ON}}$ subpopulations were tested in epithelial cell invasion assays, none of the subpopulations was invasive on its own (Figure 2C). However, the sorted SPI-1 ${ }^{\mathrm{ON}}$ subpopulations (SPI-1 ${ }^{\mathrm{ON}}$ Flag ${ }^{\mathrm{OFF}}$ and SPI-1 ${ }^{\mathrm{ON}}$ Flag ${ }^{\mathrm{ON}}$ ) showed higher invasion rates than the SPI-1 ${ }^{\text {OFF }}$ subpopulations (SPI- ${ }^{\text {OFF }}$ Flag ${ }^{\text {OFF }}$ and SPI-1 ${ }^{\text {OFF }}$ Flag ${ }^{\mathrm{ON}}$ ) 
(Figure 2C). The possibility that cell sorting might damage either the T3SS or the flagellum has been ruled out previously [3,20]. Furthermore, as a cautionary measure, the population labeled ALL (the whole bacterial population including the four subpopulations) was passed through the cell sorter before the invasion assays. The unsuspected observation that cells that express SPI- 1 and flagella are not optimally invasive might perhaps indicate that both Flag ${ }^{\mathrm{OFF}}$ and Flag ${ }^{\mathrm{ON}}$ cells are needed for optimal epithelial cell invasion, in analogy with observations made for SPI- ${ }^{\text {OFF }}$ and SPI-1 ${ }^{\text {ON }}$ cells [3].

A

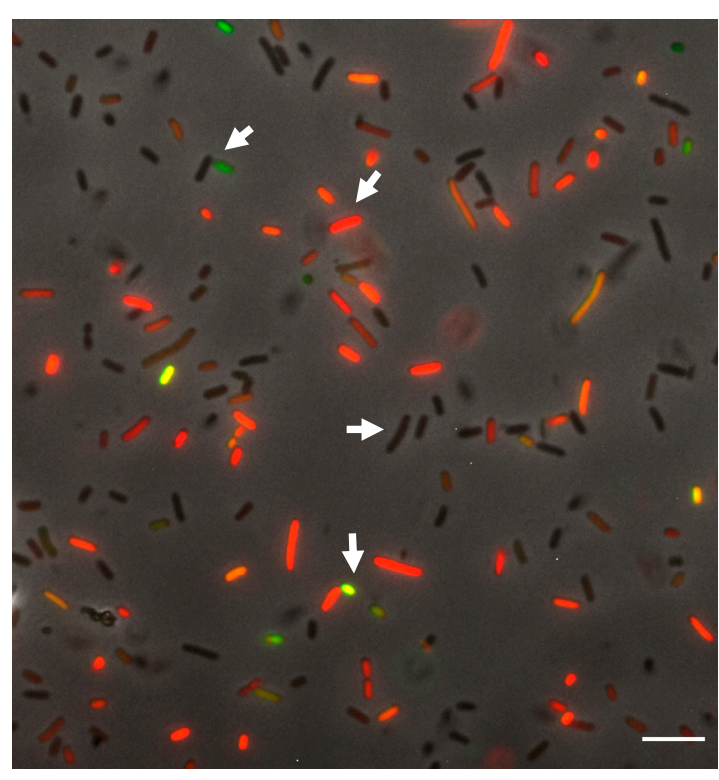

\begin{tabular}{|r|l|l|}
\hline Subpopulations & FLAGELLA & SPI-1 \\
\hline BLACK & OFF & OFF \\
\hline RED & ON & OFF \\
GREEN & OFF & ON \\
\hline YELLOW & ON & ON \\
\hline
\end{tabular}

B

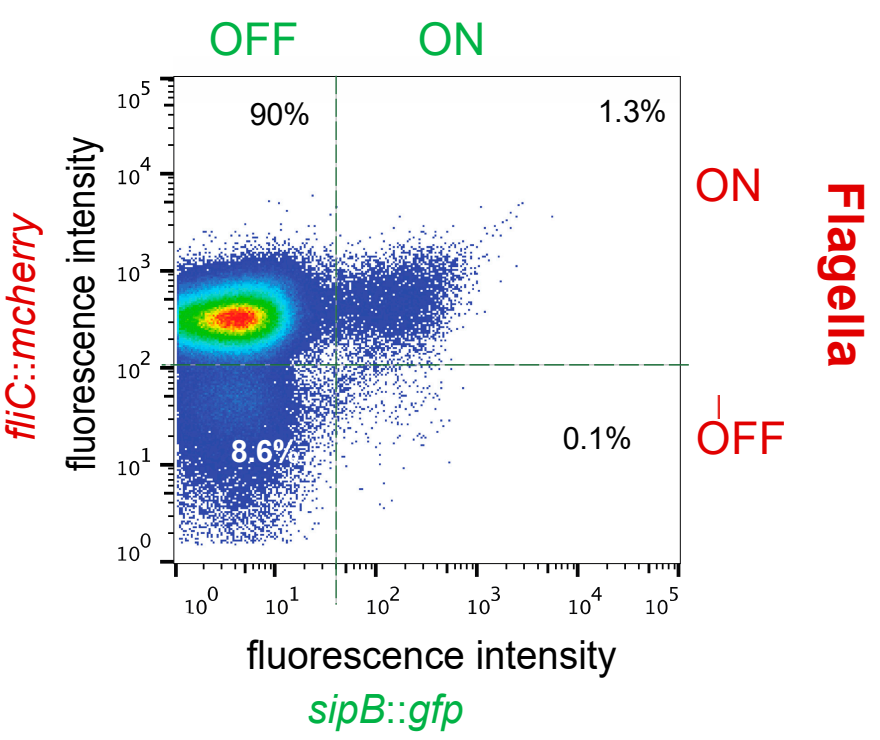

Figure 1. Single cell analysis of expression of SPI-1 (invasion) and flagellar (motility) genes. (A) A representative image of S. Typhimurium strain SV8533 (sipB::gfp fliC::mCherry) grown at $37^{\circ} \mathrm{C}$ in lysogeny broth (LB) under invasive conditions, visualized by fluorescence microscopy with a $100 \times$ objective. SPI-1 and flagellar genes are tagged with GFP and mCherry, respectively. Examples of Table $5 \mu \mathrm{m}$. (B) GFP and mCherry fluorescence intensity distribution in an LB culture of strain SV8533 under invasive conditions, monitored by flow cytometry. 
A

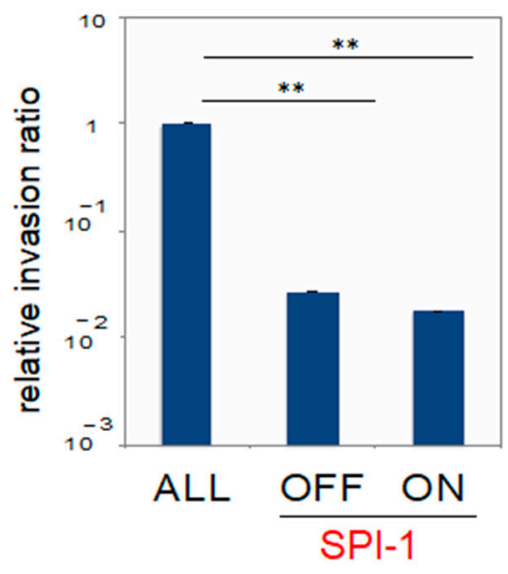

B

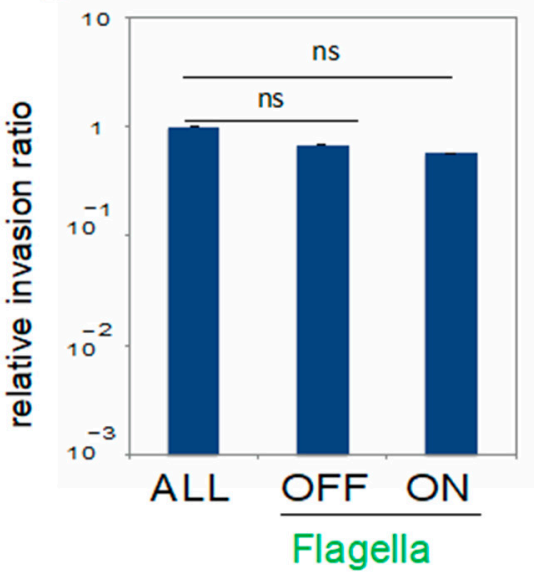

C

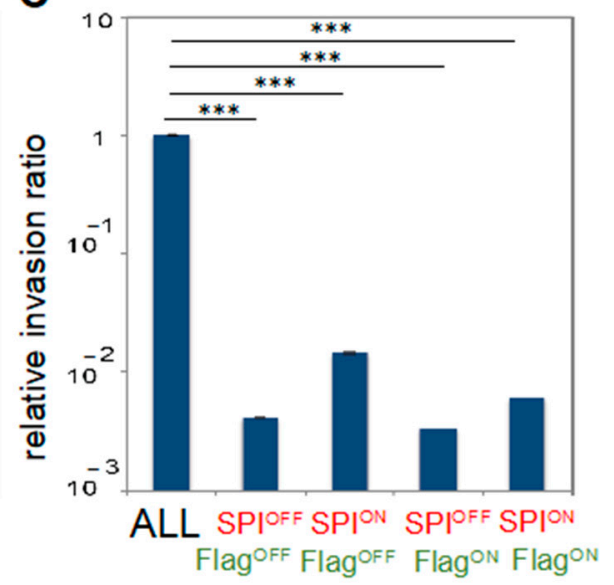

Figure 2. Invasion of epithelial cells by subpopulations expressing invasion and motility determinants (strain SV8533, sipB::gfp and fliC::mCherry). (A) Invasion rates of sorted SPI- $1^{\mathrm{OFF}}$ and SPI-1 ${ }^{\mathrm{ON}}$ subpopulations. Assays were performed using aliquots from the whole bacterial population after passage through the cell sorter ("ALL") and from SPI-1 ON and SPI-1 ${ }^{\text {OFF }}$ subpopulations. (B) Invasion rates of sorted Flag ${ }^{\mathrm{OFF}}$ and Flag ${ }^{\mathrm{ON}}$ subpopulations. Culture aliquots used in the assays were as above. (C) Invasion rates of sorted SPI-1 ${ }^{\text {OFF }}$ Flag ${ }^{\mathrm{OFF}}$, SPI-1 ${ }^{\mathrm{OFF}}$ Flag ${ }^{\mathrm{ON}}$, SPI-1 ${ }^{\mathrm{OFF}}$ Flag ${ }^{\mathrm{ON}}$, and SPI-1 ${ }^{\mathrm{ON}}$ Flag ${ }^{\mathrm{ON}}$ subpopulations. An aliquot from the whole bacterial population after passage through the cell sorter ("ALL") was included in the invasion assays. In all panels, averages and standard deviations from $>3$ independent experiments are shown. Statistical indications: $\mathrm{ns}$, not significantly different; ${ }^{* * *}$ significantly different, $p<0.001$; ${ }^{* *}$ significantly different, $p<0.01$.

\subsection{Growth of Salmonella Cells with Different Patterns of SPI-1 and Flagellar Expression}

Expression of Salmonella pathogenicity island 1 (SPI-1) is known to retard growth, thus imposing a "fitness cost" associated to synthesis of the T3SS invasion effectors [7]. Based on this antecedent, growth of $S$. Typhimurium cells harboring GFP (to monitor SPI-1 expression) and mCherry (to monitor expression of the flagellar network) was monitored by time-lapse microscopy (Figure 3 and Video S1). In the experiment summarized in Figure 3, a SPI-1 ${ }^{\text {FF }}$ Flag ${ }^{\text {OFF }}$ cell formed a colony after 5 h (black arrow) while SPI-1 ${ }^{\text {ON }}$ Flag ${ }^{\mathrm{ON}}$ individual cells (white arrows) did not form colonies. In turn, SPI-1 ${ }^{\mathrm{OFF}}$ Flag ${ }^{\mathrm{ON}}$ and SPI-1 ${ }^{\text {ON }}$ Flag ${ }^{\text {OFF }}$ cells (white circles) only began to divide when either the SPI-1 or the flagellar regulon had been switched to OFF, thus yielding SPI- ${ }^{\text {OFF }}$ Flag ${ }^{\text {OFF }}$ cells. Therefore, while the SPI- ${ }^{\mathrm{ON}}$ state causes growth retardation as previously described [7], simultaneous Flag ${ }^{\mathrm{ON}}$ and SPI-1 ${ }^{\mathrm{ON}}$ states cause growth arrest. The SPI- ${ }^{\mathrm{ON}}$ and Flag ${ }^{\mathrm{ON}}$ phenotypes do not disappear immediately when cells resume growth, and switching to OFF is observed after a few rounds of division (see Videos S1-S3). 

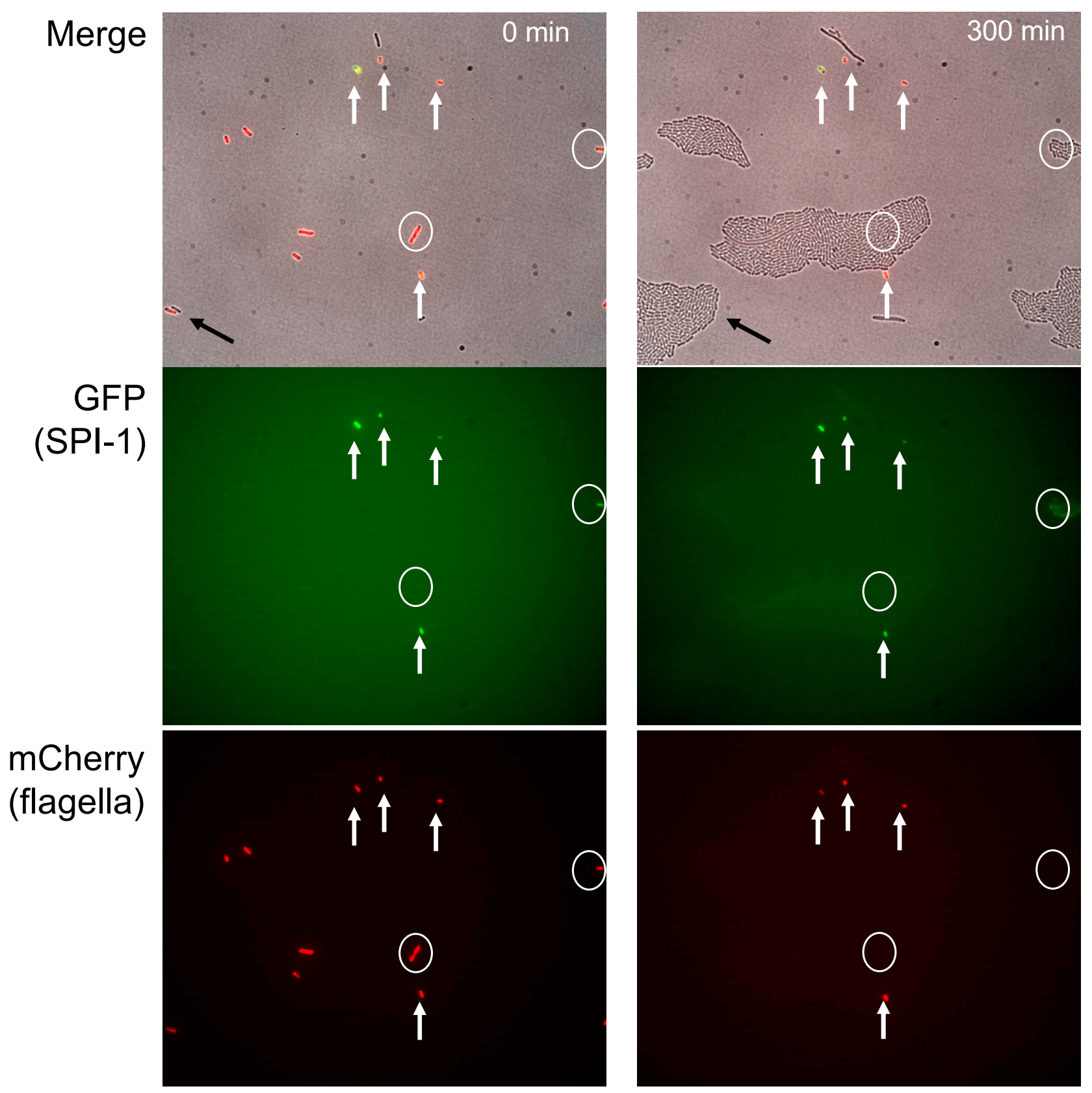

Figure 3. Time lapse microscopy analysis of growth of $S$. Typhimurium cells that differ in the expression of invasion and flagellar genes. Image from a typical time-lapse microscopy experiment with strain SV8533 (sipB::gfp and fliC:: $m$ Cherry) (left panel) and after growth on an agar pad at $37^{\circ} \mathrm{C}$ Figure $300 \mathrm{~min}$ (right panel). Bacteria were imaged to detect SPI-1 (sipB gene) and flagellar (fliC gene) expression (green and red fluorescence, respectively) and growth (phase contrast, 1 frame/10 $\mathrm{min}$ ). Flag ${ }^{\mathrm{OFF}} \mathrm{SPI}-1^{\mathrm{OFF}}$ individual cells are represented as a black arrow, Flag ${ }^{\mathrm{ON}}$ SPI-1 ${ }^{\mathrm{ON}}$ individual cells as white arrows, and Flag ${ }^{\mathrm{ON}}$ SPI-1 ${ }^{\mathrm{OFF}}$ and Flag ${ }^{\mathrm{OFF}}$ SPI-1 ${ }^{\mathrm{ON}}$ cells as white circles.

\section{Discussion}

Coordinated expression of multiple cellular systems is essential for Salmonella Typhimurium virulence. At the stage of epithelial cell invasion in the intestine, expression of pathogenicity island 1 (SPI-1) and of the flagellar gene network is regulated by interacting transcription factors $[4,5,18,21,22]$. It is also well known that both the flagellar regulon and SPI-1 exhibit bistable expression [1-3,7,8,15-18,23-25]. None of these previous studies analyzed simultaneous expression of both systems in single cells, which was the main goal 
of this study. Indeed, we have used fluorescent fusions to analyze the expression of SPI-1 and the flagellar network by microscopy (including time lapse), flow cytometry and cell sorting. Use of cell sorting circumvents the problems found in tissue culture studies using mutant strains, due to the fact that mutations that prevent biosynthesis of flagella often have pleiotropic phenotypes [26].

Simultaneous monitoring of OFF and ON states in SPI-1 and in the flagellar regulon has permitted the visualization of four subpopulations (SPI-1 ${ }^{\mathrm{OFF}}$ Flag ${ }^{\mathrm{OFF}}$, SPI-1 ${ }^{\mathrm{OFF}}$ Flag ${ }^{\mathrm{ON}}$, SPI-1 ${ }^{\mathrm{ON}}$ Flag ${ }^{\mathrm{OFF}}$, and SPI-1 ${ }^{\mathrm{ON}}$ Flag ${ }^{\mathrm{ON}}$ ), indicating that independent switching occurs (Figure 1). Hence, under gut-like growth conditions, Salmonella populations appear to contain four distinct types of cells.

An unsuspected consequence of the formation of four bacterial lineages was observed when sorted subpopulations were tested in invasion assays in vitro: none of the four subpopulations detected by flow cytometry was highly invasive (Figure 2). This observation raises the possibility that Flag ${ }^{\mathrm{OFF}}$ cells may contribute to optimal invasion, in a fashion perhaps analogous to the involvement of SPI-1 ${ }^{\mathrm{OFF}}$ cells $[3,27]$. A tentative explanation, speculative at this stage, is that evolution might have endowed Flag ${ }^{\text {OFF }}$ cells with hitherto unknown traits that favor invasion. The existence of such traits might explain why the intriguing contribution of Flag ${ }^{\mathrm{OFF}}$ cells to invasion is observed in cultured epithelial cells, that is, in the absence of immune responses. In fact, an advantage of the reductionist approach of this study may be the ability to observe interactions between flagella and epithelial cells in the absence of inflammation-related events triggered by the presence of flagella $[13,14,28]$.

Expression of the flagellar regulon enhances the growth defect of SPI-1 ${ }^{\text {ON }}$ cells; in fact, simultaneous expression of SPI-1 and the flagellar network causes growth arrest (Figure 3). One may thus understand why the subpopulation of SPI-1 ${ }^{\mathrm{ON}}$ Flag ${ }^{\mathrm{ON}}$ cells is relatively small (Figure 1). In contrast, the SPI- ${ }^{\text {OFF }}$ Flag ${ }^{\mathrm{ON}}$ subpopulation is large. Because SPI- ${ }^{\mathrm{OFF}}$ Salmonellae can invade epithelial cells $[3,27]$, possession of flagella might enhance the ability of such cells to find appropriate invasion sites.

In summary, single cell analysis adds novel features to the known roles of SPI-1 and the flagellar regulon in Salmonella invasion. The main observation is that double bistability occurs, producing four subpopulations. The possibility that SPI- ${ }^{\text {OFF }}$ Flag ${ }^{\text {OFF }}$, SPI- $1^{\text {OFF }}$ Flag ${ }^{\mathrm{ON}}$, SPI-1 ${ }^{\mathrm{OFF}}$ Flag ${ }^{\mathrm{ON}}$, and SPI-1 ${ }^{\mathrm{ON}}$ Flag $^{\mathrm{ON}}$ subpopulations cells differ in additional traits besides the presence or absence of the SPI-1 T3SS and flagella may be supported by the pleiotropic control of gene expression exerted by the master flagellar regulator, FlhDC [29]. In analogy with other bistable systems [30-32], phenotypic diversification may be advantageous over a deterministic, uniform response by bringing up division of labor and/or other benefits.

\section{Conclusions}

SPI-1 and the flagellar regulon are bistable systems with independent switching, thereby producing four subpopulations: SPI-1 ${ }^{\text {OFF }}$ Flag ${ }^{\mathrm{OFF}}$, SPI-1 ${ }^{\mathrm{OFF}}$ Flag ${ }^{\mathrm{ON}}$, SPI-1 ${ }^{\mathrm{ON}}$ Flag ${ }^{\mathrm{OFF}}$ and SPI-1 ${ }^{\mathrm{ON}}$ Flag ${ }^{\mathrm{ON}}$. However, none of the four subpopulations is highly invasive, suggesting that Flag ${ }^{\mathrm{OFF}}$ cells might contribute to optimal invasion as previously described for SPI- ${ }^{\text {OFF }}$ cells. Expression of the flagellar regulon enhances the growth impairment previously described in SPI- ${ }^{\mathrm{ON}}$ cells, and growth resumption in SPI-1 ${ }^{\mathrm{ON}}$ Flag ${ }^{\mathrm{ON}}$ cells requires switching to both SPI-1 ${ }^{\mathrm{OFF}}$ and Flag ${ }^{\mathrm{OFF}}$ states.

Supplementary Materials: The following materials are available online at https://www.mdpi. com/2076-2607/9/2/210/s1, Figure S1: Fluorescence microscopy images of S. Typhimurium cells expressing SPI-1 (GFP) and/or the flagellar regulon (mCherry). Figure S2: Single cell analysis of expression of SPI-1 (invasion) and flagellar (motility) genes at $37{ }^{\circ} \mathrm{C}$ in LB under aerobiosis. Videos S1-S3: Heterogenous expression of virulence (SPI-1) and flagellar (Flag) genes in growing microcolonies. 
Author Contributions: Conceptualization, M.A.S.-R.; methodology, M.A.S.-R. and J.C.; software, M.A.S.-R.; validation, M.A.S.-R.; formal analysis, M.A.S.-R.; investigation, M.A.S.-R.; resources, M.A.S.-R. and J.C.; data curation, M.A.S.-R.; writing-original draft preparation, M.A.S.-R.; writingreview and editing, M.A.S.-R. and J.C.; visualization, M.A.S.-R.; supervision, M.A.S.-R.; project administration, M.A.S.-R.; funding acquisition, J.C. All authors have read and agreed to the published version of the manuscript.

Funding: This study was supported by grant BIO2016-75235-P from the Spanish Ministerio de Economía, Industria y Competitividad - Agencia Estatal de Investigación and the European Regional Fund and by the VI Plan Propio de Investigación y Transferencia from the Universidad de Sevilla.

Institutional Review Board Statement: Not applicable.

Informed Consent Statement: Not applicable.

Data Availability Statement: Not applicable.

Acknowledgments: We are grateful to Modesto Carballo, Laura Navarro, and Cristina Reyes of the Servicio de Biología, CITIUS, Universidad de Sevilla, and to Alberto Álvarez of the Servicio de Técnicas Aplicadas a la Biociencia, Universidad de Extremadura, Badajoz, for help with experiments performed at the facilities. We also thank Lucía García-Pastor, David R. Olivenza, Rocio FernándezFernández, Carmen R. Beuzón and members the RED-FLAG consortium for encouragement and helpful discussions.

Conflicts of Interest: The authors declare no conflict of interest.

\section{References}

1. Bumann, D. Examination of Salmonella gene expression in an infected mammalian host using the green fluorescent protein and two-colour flow cytometry. Mol. Microbiol. 2002, 43, 1269-1283. [CrossRef] [PubMed]

2. Hautefort, I.; Proenca, M.J.; Hinton, J.C.D. Single-copy green fluorescent protein gene fusions allow accurate measurement of Salmonella gene expression in vitro and during infection of mammalian cells. Appl. Environ. Microbiol. 2003, 69, 7480-7491. [CrossRef] [PubMed]

3. Sánchez-Romero, M.A.; Casadesús, J. Contribution of SPI-1 bistability to Salmonella enterica cooperative virulence: Insights from single cell analysis. Sci. Rep. 2018, 8, 14875. [CrossRef] [PubMed]

4. Saini, S.; Ellermeier, J.R.; Slauch, J.M.; Rao, C.V. The role of coupled positive feedback in the expression of the SPI1 type three secretion system in Salmonella. PLoS Pathog. 2010, 6, e1001025. [CrossRef] [PubMed]

5. Singer, H.M.; Kühne, C.; Deditius, J.A.; Hughes, K.T.; Erhardt, M. The Salmonella Spi1 virulence regulatory protein HilD directly activates transcription of the flagellar master operon flhDC. J. Bacteriol. 2014, 196, 1448-1457. [CrossRef]

6. Hamed, S.; Wang, X.; Shawky, R.M.; Emara, M.; Aldridge, P.D.; Rao, C.V. Synergistic action of SPI-1 gene expression in Salmonella enterica serovar Typhimurium through transcriptional crosstalk with the flagellar system. BMC Microbiol. 2019, 19, $211-212$. [CrossRef]

7. Sturm, A.; Heinemann, M.; Arnoldini, M.; Benecke, A.; Ackermann, M.; Benz, M.; Dormann, J.; Hardt, W.-D. The cost of virulence: Retarded growth of Salmonella Typhimurium cells expressing type III secretion system 1. PLoS Pathog. 2011, 7, e1002143. [CrossRef]

8. Arnoldini, M.; Vizcarra, I.A.; Peña-Miller, R.; Stocker, N.; Diard, M.; Vogel, V.; Beardmore, R.E.; Hardt, W.-D.; Ackermann, M. Bistable expression of virulence genes in Salmonella leads to the formation of an antibiotic-tolerant subpopulation. PLoS Biol. 2014, 12, e1001928. [CrossRef]

9. Jones, G.W.; Richardson, L.A.; Uhlman, D. The invasion of HeLa cells by Salmonella typhimurium: Reversible and irreversible bacterial attachment and the role of bacterial motility. J. Gen. Microbiol. 1981, 127, 351-360. [CrossRef]

10. Misselwitz, B.; Barrett, N.; Kreibich, S.; Vonaesch, P.; Andritschke, D.; Rout, S.; Weidner, K.; Sormaz, M.; Songhet, P.; Horvath, P.; et al. Near surface swimming of Salmonella Typhimurium explains target-site selection and cooperative invasion. PLoS Pathog. 2012, 8, e1002810. [CrossRef]

11. Zarkani, A.A.; López-Pagán, N.; Grimm, M.; Sánchez-Romero, M.A.; Ruiz-Albert, J.; Beuzón, C.R.; Schikora, A. Salmonella heterogeneously expresses flagellin during colonization of plants. Microorganisms 2020, 8, 815. [CrossRef] [PubMed]

12. Chaban, B.; Hughes, H.V.; Beeby, M. The flagellum in bacterial pathogens: For motility and a whole lot more. Semin. Cell Dev. Biol. 2015, 46, 91-103. [CrossRef] [PubMed]

13. Hayashi, F.; Smith, K.D.; Ozinsky, A.; Hawn, T.R.; Yi, E.C.; Goodlett, D.R.; Eng, J.K.; Akira, S.; Underhill, D.M.; Aderem, A.; et al. The innate immune response to bacterial flagellin is mediated by Toll-like receptor 5. Nature 2001, 410, 1099-1103. [CrossRef] [PubMed]

14. Gewirtz, A.T.; Simon, P.O.; Schmitt, C.K.; Taylor, L.J.; Hagedorn, C.H.; O’Brien, A.D.; Neish, A.S.; Madara, J.L. Salmonella typhimurium translocates flagellin across intestinal epithelia, inducing a proinflammatory response. J. Clin. Investig. 2001, 107, 99-109. [CrossRef] [PubMed] 
15. Stewart, M.K.; Cookson, B.T. Mutually repressing repressor functions and multi-layered cellular heterogeneity regulate the bistable Salmonella fliC census. Mol. Microbiol. 2014, 94, 1272-1284. [CrossRef]

16. Cummings, L.A.; Wilkerson, W.D.; Bergsbaken, T.; Cookson, B.T. In Vivo, fliC expression by Salmonella enterica serovar Typhimurium is heterogeneous, regulated by ClpX, and anatomically restricted. Mol. Microbiol. 2006, 61, 795-809. [CrossRef]

17. Koirala, S.; Mears, P.; Sim, M.; Golding, I.; Chemla, Y.R.; Aldridge, P.D.; Rao, C.V. A nutrient-tunable bistable switch controls motility in Salmonella enterica serovar Typhimurium. mBio 2014, 5. [CrossRef]

18. Saini, S.; Slauch, J.M.; Aldridge, P.D.; Rao, C.V. Role of cross talk in regulating the dynamic expression of the flagellar Salmonella pathogenicity island 1 and type 1 fimbrial genes. J. Bacteriol. 2010, 192, 5767-5777. [CrossRef]

19. Datsenko, K.A.; Wanner, B.L. One-step inactivation of chromosomal genes in Escherichia coli K-12 using PCR products. Proc. Natl. Acad. Sci. USA 2000, 97, 6640-6645. [CrossRef]

20. García-Pastor, L.; Sánchez-Romero, M.A.; Gutiérrez, G.; Puerta-Fernández, E.; Casadesús, J. Formation of phenotypic lineages in Salmonella enterica by a pleiotropic fimbrial switch. PLoS Genet. 2018, 14, e1007677. [CrossRef]

21. Chubiz, J.E.C.; Golubeva, Y.A.; Lin, D.; Miller, L.D.; Slauch, J.M. FliZ regulates expression of the Salmonella pathogenicity island 1 invasion locus by controlling HilD protein activity in Salmonella enterica serovar Typhimurium. J. Bacteriol. 2010, 192, 6261-6270. [CrossRef] [PubMed]

22. Mouslim, C.; Hughes, K.T. The effect of cell growth phase on the regulatory cross-talk between flagellar and Spi1 virulence gene expression. PLoS Pathog. 2014, 10, e1003987. [CrossRef] [PubMed]

23. Diard, M.; Sellin, M.E.; Dolowschiak, T.; Arnoldini, M.; Ackermann, M.; Hardt, W.-D. Antibiotic treatment selects for cooperative virulence of Salmonella typhimurium. Curr. Biol. 2014, 24, 2000-2005. [CrossRef] [PubMed]

24. Freed, N.E.; Silander, O.K.; Stecher, B.; Böhm, A.; Hardt, W.-D.; Ackermann, M. A simple screen to identify promoters conferring high levels of phenotypic noise. PLoS Genet. 2008, 4, e1000307. [CrossRef] [PubMed]

25. Stewart, M.K.; Cummings, L.A.; Johnson, M.L.; Berezow, A.B.; Cookson, B.T. Regulation of phenotypic heterogeneity permits Salmonella evasion of the host caspase-1 inflammatory response. Proc. Natl. Acad. Sci. USA 2011, 108, 20742-20747. [CrossRef]

26. Winter, S.E.; Thiennimitr, P.; Nuccio, S.-P.; Haneda, T.; Winter, M.G.; Wilson, R.P.; Russell, J.M.; Henry, T.; Tran, Q.T.; Lawhon, S.D.; et al. Contribution of flagellin pattern recognition to intestinal inflammation during Salmonella enterica serotype Typhimurium infection. Infect. Immun. 2009, 77, 1904-1916. [CrossRef]

27. Ginocchio, C.; Pace, J.; Galán, J.E. Identification and molecular characterization of a Salmonella typhimurium gene involved in triggering the internalization of Salmonellae into cultured epithelial cells. Proc. Natl. Acad. Sci. USA 1992, 89, 5976-5980. [CrossRef]

28. Olsen, J.E.; Hoegh-Andersen, K.H.; Casadesús, J.; Rosenkranzt, J.; Chadfield, M.S.; Thomsen, L.E. The role of flagella and chemotaxis genes in host pathogen interaction of the host adapted Salmonella enterica serovar Dublin compared to the broad host range serovar S. Typhimurium. BMC Microbiol. 2013, 13, 67. [CrossRef]

29. Soutourina, O.A.; Bertin, P.N. Regulation cascade of flagellar expression in Gram-negative bacteria. FEMS Microbiol. Rev. 2003, 27, 505-523. [CrossRef]

30. Dubnau, D.; Losick, R. Bistability in bacteria. Mol. Microbiol. 2006, 61, 564-572. [CrossRef]

31. García-Pastor, L.; Puerta-Fernández, E.; Casadesús, J. Bistability and phase variation in Salmonella enterica. Biochim. Biophys. Acta 2019, 1862, 752-758. [CrossRef] [PubMed]

32. Cota, I.; Sánchez-Romero, M.A.; Hernández, S.B.; Pucciarelli, M.G.; Gel Portillo, F.G.; Casadesús, J. Epigenetic control of Salmonella enterica O-antigen chain length: A tradeoff between virulence and bacteriophage resistance. PLoS Genet. 2015, 11, e1005667. [CrossRef] [PubMed] 